\title{
A Study on Bisri Mustofa, Haji Abdul Malik Karim Amrullah [Hamka] and Quraish Shihab's Tafsîr on Isrâ‘îliyyât
}

\author{
Achmad Murtafi Haris \\ UIN Sunan Ampel, Surabaya \\ amharis05@gmail.com \\ Sri Margana \\ Universitas Gadjah Mada, Yogyakarta \\ s.margana@gmail.com \\ Al Makin \\ UIN Sunan Kalijaga, Yogyakarta \\ nabiy13@yahoo.com
}

\begin{abstract}
Muslims are now cynical about isrâîliyat stories, which come from the Jews and Christians. This intellectual phenomenon is contrary to the initial Muslim response are familiar with the material isrấîlŷât. This study tries to dissect isrấîliyat stories written by Bisri, Hamka and Quraish in the interpretation of each: Tafsîr al-Ibrîz, Tafsîr al-Az̧har, and the Tafsîr al-Mişbah. Press the point of this article is the background of which influence their perception in interpreting the verses isrâtilyatat. This article uses qualitative methods and approaches to determine the intellectual history of the development of human ideas on certain issues. The paper ends at the conclusion that Bisri's tolerance and Hamka and Quraish's rejection isrấilityat influenced by social background and academic respectively.

[Umat Islam sekarang sinis terhadap kisah isrâ'îliyât atau kisahkisah yang berasal dari Yahudi dan Kristen. Fenomena intelektual ini bertentangan dengan respons Muslim awal yang akrab dengan materi-materi isrấlilyât. Penelitian ini mencoba untuk membedah kisah-kisah isrâ'tlîyat yang ditulis oleh Bisri, Hamka, dan Quraish dalam tafsir masing-masing: Tafsîr al-Ibrî̌,
\end{abstract}


Tafsîr al-Ažhar, dan Tafsîr al-Mişbah. Titik tekan dari artikel ini adalah latar belakang yang kemudian mempengaruhi persepsi mereka dalam menafsir ayat-ayat isrấlilyât. Artikel ini menggunakan metode kualitatif dan pendekatan sejarah intelektual untuk mengetahui perkembangan ide manusia pada isu tertentu. Makalah ini berakhir pada kesimpulan bahwa sikap toleransi Bisri dan penolakan Hamka dan Quraish isrấlikyât dipengaruhi oleh latar belakang sosial dan akademik masingmasing.]

Keywords: Tafsîr, Isrầłlliyât, Indonesian Mufassir, Social Context.

\section{Introduction}

Muslims in different parts of the world, nowadays, rejects the use of isrấlilyat t or stories of Jewish-Christians sources in their tafsîr discourse. The rejection does not merely come from academic field but become social movement in a kind of the campaign of anti-isrấnliy ât to all Muslims. This is certainly in contrast to the early Muslim tradition whom they are aware to use such things for some benefits. The Prophet's companions on some issues particularly related to the story of the Israelite, referred to their colleagues of ex-Jews and Christians to explain some concise stories in the Qur'ân. Even the Prophet himself delivered the experience of Tamîm al-Dârî when stranded to an island where he met with the figure of Dajjâl.

In many classical tafsîr books the abundance of isrâ îlîy ât are found while the contemporary tafsir books eliminated them and are even offensive to it. Some of those that included isrâtilîyat are al-Baghawî, alJalâlayn, and al-Khâzin. While the contemporary tafsîr that exclude it are Tafsîr al-Manâr and Tafsîrfî Zilâl al-Qur'ân. The work of Indonesian mufassir. Tafsîr al-Ibriz by Bisri Mustofa, Tafsir al-Ažbar by Hamka and Tafsir AlMisbah by Quraish Shihab are subject to clarification about each one position on Isrâiliyatat. Those three tafsîr are on the research because each represents Indonesian Muslim majority of traditionalist, modernist and academia. Thus the research would investigate their views and perceptions on isrấlilyat and how do they interpret the stories in the Qur'ân. The 
research uses qualitative method to explain the intellectual phenomenon on isrấlilyat. Since the object is on three mufassir paradigm, this research uses a comparative model and an Intellectual History approach. The development of human paradigm in their pro and contra on a certain issue require each one's political and social background studies in purpose of knowing the situation behind and above human paradigm change. The research data will primarily base on literatures of the three mufassir and will secondarily use other related sources. Interview with experts like Prof. Mahmoud Ayoub also is undergone to broaden theoretical insight. This research employs the theory of Myth-Logos and Tolerance Law of Raymond Panikkar.

\section{Arab's Social Intercourse with Jews and Christians}

Isrâtiliyat is the product of cultural exchange between Arabs, Jews and Christians in early Islamic period. The Arabian Peninsula, mainly the northern part, was the cradle of the Semitic people and in the southwestern parts was a place of the Islamic birth where Muhammad at the first time spread his message to all part of the peninsula. People in different beliefs and cultures inhabited in the northern part following their travelling in the route of Palestine-Egypt. Bible mentioned about this land where Israelites and the various tribes of the Peninsula engaged in trades and other economics and social activities. The relation between the Jews and the Arabs has appeared in the Talmud telling that Jews lived largely in the Northeastern Arabia. ${ }^{1}$

The location of Arabian Peninsula that was between two gigantic empires: Byzantium and Persia was the frontier place where many people of the oppressed destined there when looking of the shelter. The desert that stretches along peninsula boundary was the natural barrier from other military invasion. ${ }^{2}$ Among those people were Jews and Christians who faced intimidation from their rulers. Jews led by Moses resisted persecution of Pharaoh, the king of Ancient Egypt, and escaped from

\footnotetext{
1 Moshe Perlmann, "Apostasy to Islam" in Fred Skolnik \& Michael Berenbaum, Encyclopaedia Judaica, Vol. 2 (Detroit: Thomson Gale, 2007), 275.

2 D.S. Margoliouth, The Relation between Arabs and Israelites Prior to the Rise of Islam (London: The British Academy, 1924), 1.
} 
troop pursuit by crossing the Red Sea after God endowed Moses with the miracle to split the sea for running away. ${ }^{3}$

Maissonneve \& Larose, in Abraham Journey to Mecca in Islamic Tafsîr, say that Jews, Christians, and indigenous Arabian groups lived together and settled in major settlements in the cities of Yathrib (Medina), Khaybar, and al-Ṭ̂a'if long before the birth of Muhammad. They said: "Jewish, Christian, and other Arabs engaged in plenty of social intercourses in dayto-day activities as well as during the annual fairs. The various groups' affairs however led to the hearing of each other's stories and tales during the course of daily life. There is no reason to preclude the possibility of non-orthodox Jews and Christians entering the Hijaz and exerting an influence upon the local lore as well." ${ }^{4}$

Jews found their shelter in the area since they were not discriminated and exempted from any social and economic activities. They had land property that they could inherit it to their children. They were not exempted from trades and other occupations and had full freedom living in the Arab land. The cultural learning curve between the Jews, Christians and Arabs occurred and all spoke in Arabic like a native Arab. ${ }^{5}$ The strict tendency in enduring religious orthodoxy, however, could not stop social intercourse and cultural exchange between different religious

3 Book of Exodus: 13:17-14:29; Qur'an [the Poet] 26: 60-67; Ahmad Shalabî, AlYabûdîyah (Cairo: Maktabah al-Nahḍah al-Mișrîyah, 1996), 72; see also Eli Barnavi, $A$ Historical Atlas of the Jewish People, from the Time of Patriarch to the Present (New York: Alfred A. Knop, 1992), 31; I see that to cross Red Sea from Egypt is likely to begin from Suez Canal and to end at the area of Mountain Sinai or to end at Hejaz if they crossed from Luxor, the city of where the Pharaoh's palace located. From there they went forth to the north to the mountain of Sinai, which is now part of Egypt after for some decades under Israel territory.

4 The interesting part of my quotation from Maissonneve is the mentioning 'nonorthodox' Jews who exchanged lore that seems to exclude the orthodox Jews from that practice or it tells that mostly the Jewish settler in that time were among non-orthodox or heterodox not among the orthodox one. Besides, it also implies that the cultural exchange effortlessly actualized in non-orthodox Jews while the orthodox one prefer to keep their identity and tradition consistently amid the Arab culture domination. See Reuven Firestone, “Abraham's Journey to Mecca in Islamic Exegesis: A Form-Critical Study of a Tradition," Studia Islamica, no. 76 (1992): 5-24.

5 'Abd al-Wahhâb Muhammad al-Musîrî, Mawsû̀ât al-Yahûd wa al-Yabûdîyah wa alȘabyûnŷyah (Cairo: Dâr al-Shurûq, 2015), 245. 
adherents. This phenomenon continued during the prophet Muhammad life and after his decease when some Jews and Christians converted to Islam and brought their traditions (isrấilîyât) into Islamic scholarship mainly in the discipline of tafsîr.

\section{Mythos, Logos and the Law of Tolerance}

Talking about isrấlilyât is talking about myths or stories being taken for granted without verification. Raymond Panikkar, in talking about Mythos and Logos, has presented a very fundamental insight on the myth and how people of the ancient adopted while the contemporaries rejected. He said that myth is not the object of discourse but the expression of a sui generis form of consciousness. Myth and wisdom go together as mentioned by Aristotle in his Metaphysics, that the lover of myth is a sort of philosopher, a lover of wisdom. Myth is that what people take it for granted. It is unquestioned, especially the living myth, because, de facto, it is not seen as questionable. Myth is transparent and the mythical story is only the form. ${ }^{6}$

In further explanation, Panikkar said that myth should not be interpreted using hermeneutics. Myth lives in his realm and what hermeneutics can reach in his interpretation on a myth is considered as logos. On the other hand, Mythos and logos are oppositions one another. What logos can reach regarding a myth, Panikkar prefers to put it in an intermediary position. Myth is neither an object of thought nor does it support it. Myth functions to purify and bypass thought, so that the unthought-of may emerge and the intermediary disappear. ${ }^{8}$

In obvious statement, Panikkar said: "Myth is the salutary of thinking; it liberates us from the burden of having to think out and think through everything and thus it opens up the realm of freedom: not mere the liberty of choice but the freedom of being. When the thinking has not

\footnotetext{
${ }^{6}$ R. Panikkar, Myth, Faith, and Hermeneutics (Bangalore: Asian Trading Corporation, 1983), 4.

7 Hermeneutics has three functions: Morphological Function, which is about the meaning of the word and its derivative; Diachronical Function, which is to bridge the gap of time between the author and the reader; Diatopical function which is to bridge between different person or human generation between the author and the reader. See Ibid., 8-9.

${ }^{8}$ Ibid., 4.
} 
yet landed on the thought so that it cannot yet know what is being thought in the thinking, we are still in domain of the myth." This statement does not mean to despise the value of thought and logos. It only to mean that what human being has in his mind can be reduced to neither logos nor a human's awareness to a reflective consciousness.

Myth is like faith being believed subjectively. Faith is a man's dimension that corresponds to the myth. Man is open to an ever-growing horizon of awareness provided of the myth. Belief is the vehicle by which human consciousness passes form mythos to logos. Human reflection of belief can be on the fact of believing or on the content of belief. For the former, it implies no elucidation since someone has fallen into certain belief. For the latter, it is interesting to observe whether someone has fallen into certain belief without understanding the content or it might be, by understanding the content, he has destroyed the belief and unconsciously has converted to knowledge or he did move from mythos to logos. This is what in the Latin Middle Ages so called as the incompatibility between the Cognitum and Creditum or what is known and what is believed. ${ }^{10}$

In talking about the issue of mythos and logos, especially in discussing contemporary connection between ideology ${ }^{11}$ and 'Demythicization', Panikkar offers the Law of Tolerance rooted in the anthropology. He said that tolerance is directly proportional to the myth you live and inversely proportional to the ideology you follow. Myth is always the accepted horizon within which human places his experience of truth. Myth is what makes someone becomes unique and hence is irreplaceable and being tolerated by others. Meanwhile, ideology, in the contrary, is the demythycized part of someone's view of the world. Ideology always put human in the distance from the object by putting it in the historical moment. ${ }^{12}$

\footnotetext{
${ }^{9}$ Ibid., 5.

10 Ibid.

${ }^{11}$ Ideology is a system of ideas formulated by logos, which is incapable of transcending its own temporary. This incapability will become a problem when inversely ideology feels capable to encompass his temporal characteristics. See, ibid., 21. The difference between ideology and philosophy is that the former put practice before theory; while the later put the theory before the practice. See Ibid., 28.

12 Ibid., 20-21.
} 
Following Pannikar's Law of Tolerance, living within myth will lead to the tolerance more than living within ideology. The more perfect the ideology, the less tolerant it is. In ideological system, the tolerance is an exception. But the more ideologically perfect society, the more these exceptions are reduced to a minimum. There is no room for tolerance in a perfect ideology. For the imperfect ideology or that is on the way to the perfectness, ideology must put up with tolerance. The perfect ideology is a totalitarian ideology that tries to encompass the limit of the temporary and human experience. In this case, he becomes absolutely intolerant to anybody, individually or institutionally who does not submit to him. Tolerance by means of an exceptional procedure is considered the very index of ideology's weakness. ${ }^{13}$

\section{Mufassir's Background and the Persception of Isrâ'îlîyât}

The Intellectual history of Muslim scholars have developed and been constructed by the horizon of Mythos and Logos. Their migration from the former to the later horizon drove them from the stage of conserving the existing paradigm to the stage of criticizing it. The same trend changing is expected to happen in the context of Indonesia. The heat polemic among Middle Eastern scholars on theological, social and political issues reached its resonance to the archipelago (Indonesia) and suddenly inspired Indonesian Muslims to follow the same trend.

The division of Indonesian Muslim into traditionalist and modernist of M.C. Ricklefs is helpful in implementing the theory of mythos and logos horizon. ${ }^{14}$ The traditionalist who defends the existed paradigm and the modernist who prefer to be in the opposite side indicate the former as if living under the first horizon and the later under second one. The insistence of the traditionalist to conserve the established paradigm causes them to develop a propagation method through local language and cultural tool enhancement as said by Panikkar. Meanwhile The zeal of the modernist to generate social change causes them to develop a new religious paradigm that is believed to be more responsive to the social

\footnotetext{
13 Ibid., 25.

14 M. C. Ricklefs, A History of Modern Indonesia since c. 1300 (Hampshire: Palgrave MacMillan, 2001), 222-223.
} 
transformation. The exposition of mufassir's keenness in implementing his paradigm or ideology in the society and in responding social problem will reveal the degree of scholar's ideological extremity.

\section{Bisri Mustofa's Biography and Isrâ'îlîyât}

Bisri Mustofa was born in Rembang December 31, 1915 and died February 17, 1977. He was Indonesian Muslim scholar and productive author whose works being published and widely circulated particularly among Muslim villagers in Java. He accomplished writing his masterpiece Tafsîr al-Ibriz li Ma'rifah al-Qur'ân al-'Až̨zin 1960. The book has 2270 pages and consists of three volumes. KH. Saifuddin Zuhri (1919-1986CE), the former Indonesian Minister of Religious Affairs was impressed by Bisri Mustofa saying that he was a famous religious cleric, a productive author and the attractive orator. ${ }^{15}$

Bisri was raised in a religious family and pesantren (Islamic boarding school) that belongs his father. He went to formal and informal education and was the student of Ongka Loro (Dutch: Vervolgschool), the secondary school in Rembang. He did not finish his study at Ongko Loro and was obliged to leave the school in the next two years for accompanying his father's pilgrimage to Mecca. After coming home from Makkah, Bisri continued study at Holland Indische School (HIS) very shortly and was compelled by Kiai Cholil to break from the school and came back to Ongka Loro until finished the secondary school. Later on, Bisri studied at Pesantren Kajen and Kasingan that were headed by Kiai Cholil (1930). ${ }^{16}$

Bisti's academic portfolio was dominated by traditional education of Pesantren and reading courses in Mecca. The formal education at Ongko Loro Rembang has influenced him as well in raising nationalism. Although Ongko Loro School, which literally means the School Number Two belonged to the Dutch but he taught Indonesian nationalism. The school was founded in response to the high indigenous students demand to continue study after they were unaccepted to study in the private

\footnotetext{
15 H. Soeleiman Fadeli, Antologi NU: Sejarah, Istilah, Amaliab Uswah (Surabaya: Khalista, 2007), 199-203.

${ }^{16}$ Ibid.
} 
schools. Ongko Loro School system was similar to the HIS, which is special for Dutch student that adopted a secular system. ${ }^{17}$

In his elderly Bisri Mustofa was famous cleric among Indonesian traditional Muslim. He dedicated himself to Nahdlatul Ulama (NU), the largest Islamic organization in Indonesia that indicates his grassroots, tradition and ideology. The question remains on what is the real ideology of Nahdlatul Ulama? In fact, the history of the NU's birth was in response to the coming of Wahhabism to the country. Since the new comer had the agenda of purifying Islamic traditions usually performed by Muslim majority of the country, the existing leaders were called to fortify the traditionalist paradigm by founding Nahdlatul Ulama. ${ }^{18}$

Comparing to the revivalist group paradigm that adopted Puritanism and rationalism, traditionalist prefers to conserve some traditions that partly stem from Sufi and Shi'ite tradition. Wali Songo (the Nine Muslim Saints), the disseminator of Islam in Java Island, are known as the Sufi figures. ${ }^{19}$ Sufis paradigm adores esoteric teaching and emphasizes spiritual enrichment: nafs, self and soul. ${ }^{20}$ Sufis paradigm is in accordance with Gus Dur's idea that Islam should present its intrinsic part rather than its legal-formal aspect. ${ }^{21}$ Sufis' fondness to esoteric make them deal with the myth and metaphysic dimension. In this stage, Sufis paradigm will interact with isrấlilyat that tell about esoteric and spiritualism. The stories of the pious figures and prophet who lived in the ancient time were abundant in the legacy of the children of Israel are much cited in the books of Sufism.

Although the people of NU are varied in responding the myth, they share the same value of belief in occult matters more than the Muslim

\footnotetext{
${ }^{17}$ Nasruddin Anshoriy dan Pembayun, Pendidikan Berwawasan Kebangsaan: Kesadaran Ilmiah Berbasis Multikuluralisme (Yogyakarta: LKIS, 2008), 50.

${ }^{18}$ Harry Jindrich, "Indonesia Islam Under the Japanese Occupation, 1942-45," paper at the Annual Conference of the Far Eastern Association, March 1955, Washington D.C., 352.

${ }^{19}$ Mochtar Lubis, Indonesia, Land under the Rainbow (Singapore: Oxford University Press, 1987), 60.

20 Anna-Teresa Tymieniecka, ed., Reason, Spirit, and the Sacral in the New Inlighment: Islamic Metaphisics Revived and Recent Phenomenology of Life (New York: Springer, 2011), 12.

${ }^{21}$ Howard M. Federspiel, Persatuan Islam Islamic Reform in Twentieth Century Indonesia (New York: Monograph Series Cornell Unversity, 1970), 69.
} 
modernist. The example of the myth that circulates among NU community is the story narrated by Mustofa Bisri familiarly known as Gus Mus, the son of Bisri Mustofa who met someone from Cirebon, West Java. The stranger said to Gus Mus that he just met his father (the deceased) and left the message to be delivered to him (Gus Mus). The message mentioned that Mustofa Bisri should correct a little mistake in his father's book, Tafsir al-Ibrî, chapter of al-Fath. Mustofa asked the person: "When did you meet him?" The person answered: "Yesterday I met him." The answer of the man is astonishing because the father passed away 40 days ago. The person has been shocked more when he heard that the father has deceased for longer than a month. ${ }^{22}$

Bisri's interaction with isrấilîyat also occurred during his study in Saudi Arabia and Indonesia during which he read some tafsîr books that contained isrấilîyat. Such as Tafsîr al-Kashshâf of Zamakhsharî that uses isrấlilyat to interpret QS. al-Baqarah [2]: 34-36 which tells the way iblis entered the garden of Eden after his expel from the heaven. Zamakhsharî said that being headed with a number of barriers, iblis got idea to enter the serpent's mouth on his way to Paradise. Having been in the Paradise, iblis came out from the serpent's mouth and did his agenda to seduce Eve to eat the fruit from the forbidden tree. ${ }^{23}$

Another tafsîr book read by Bisri in Mecca that contain isrấrlityat was Tafsir Jalalayn. This book tells the story of Eve creation that she was made from Adam's left rib. ${ }^{24}$ Although the author of al-Kashshâf and alJalalayn affiliates to the different school they shared the same employment of isrấlilyat in their works. Al-Zamakhsharî, the author of al-Kashshâf affiliated to $\mathrm{Mu}^{\prime}$ tazilite school that develops rationalism and Jalâl al-Dîn al-Mahallî and Jalâl al-Dîn al-Suyûtûi the owners of Tafsîr al-Jalâlayn affiliate to Ahl al-Sunnah wa al-Jamâ'ah that develop orthodoxy and scripturalism. ${ }^{25}$ This fact obviously tells that both rationalist and

\footnotetext{
22 Samsul Munir Amin, Karomah Para Kiai (Yogyakarta: Pustaka Pesantren, 2009).

${ }^{23}$ Abû al-Qâsim Maḥmûd b. 'Amr al-Zamakhasharî, Tafsîr al-Kashshâf, Vol. 4 (Beirut: Dâr al-Kutub, 1407), 127.

${ }^{24}$ Jalâl al-Dîn Aḥmad al-Mahallî dan Jalâl al-Dîn al-Suyûtîi, Tafsîr al-Jalâlayn (Cairo: Dâr al-Hadîth, 1980), 9

25 There are some books vastly circulated in Indonesia, such as Tafsîr al-Jalâlayn (Quranic comentaries of the two Jalâl), Kitâb Arbaîn (book of forty traditions) by Shaykh Nawawi
} 
scripturalist Muslim scholars of early period support the use of isrấlilyat and were undisturbed by the use of Biblical sources.

In his preface of al-Ibrîz li-Ma'rifat Tafsîr al-Qur'ân al-'Až̀z, Bisri asserted that he aimed from writing the book to deliver the easy interpretation to understand (Javanese: enteng sarta gampil fahamanipun). He said that what he has done is simply to pick from the authoritative tafsir books (tafâsîr mu'tabarah) such as Tafsîr al-Jalâlayn, Tafsîr al-Baydânî, Tafsìr Khârin, etc (Javanese: namung methik saking tafasir mu'tabarah kados tafsir...). ${ }^{26}$ The last part of the sentence that mentions his references of among authoritative books is much important. Bisri therefore was among traditionalist scholar who submitted to and acknowledged the existence of an intellectual authority. This confession is also adopted by Nahdlatul Ulama to keep the validity of their doctrine through reliable chain of transmission (sanad).$^{27}$

Bisri adoption of isrât chlyât appears in his interpretation on the story of 'Moses vs. Pharaoh Magicians' in al-A'râf [7]: 112-117, ${ }^{28}$ Bisri said:

"when the day came, 72 magicians (sâhir) gathered in the certain place.

People from all over the country, the old and young, the big, the boys to the little kids (Javanese: sak cindil abange pisan) all of them together watch the contest in the square. Pharaoh with his mans were on the stage. The arena was in the middle besieged by hundred thousand of the people. Having all crowded the arena, on the scheduled time Moses accompanied by Aaron came. Following both coming, the people were noising and the

al-Bantani, the Nayl al-Awtâr (the serenity of the hopeful) by al-Imâm al-Shawkânî has been the book of standards of Muslim behavior. See Howard M. Federspiel, Popular Indonesian Literature of the Qur'an (New York: Cornell Modern Indonesian Project, 1994), 11.

${ }^{26}$ Bisri Mustofa, Al-Ibrîz li Ma'rifat Tafsîr al-Qur'ân al-Ažîz Vol. 1 (Kudus: Maktabah Menara Kudus, t.th.).

27 Abdul Muchith Muzadi, Mengenal Nabdlatul Ulama (Jember: Masjid Sunan Kalijaga, 2006), 12.

28 112. and bring up to Thee all (our) sorcerers well-versed."; 113. so there came the sorcerers to Pharaoh: They said, "Of course we shall have a (suitable) reward if we win!"; 114. He said: "Yea, (and more),- for ye shall In that case be (raised to posts) nearest (to My person)."; 115. They said: "O Moses! wilt Thou throw (first), or shall we have the (first) throw?”; 116. said Moses: “Throw ye (first)." so when They threw, They bewitched the eyes of the people, and struck terror into them: for They showed a great (feat of) magic; 117. we put it into Moses's mind by inspiration: "Throw (now) Thy rod": and Behold! it swallows up straight away all the falsehoods which They fake! 
magicians limped looking at the prophet's confidence. The magicians said in their hearts, if Moses wins it is not because of the magic otherwise he will be defeated. The contest began and the magicians offered Moses to throw his stick. Moses rejected and asked the magicians to do it first. The magicians threw their ropes and sticks and became so much little snakes. Then, God revealed Moses to throw his stick that suddenly turned to the big snake and swallowed those snakes of the magicians." 29

Bisri explained that the reason of Moses win was due to the miracle given by God that can truly turn the thing. It was not a magic that only sight tricking. Magic is not a real otherwise magician would turn the stone to the gold so that he becomes a rich man and leaves his work but he cannot. ${ }^{30}$

Being angry of the defeat, Pharaoh became more sadistic to the Children of Israel. He killed all males and let the females alive. Feeling Suffered from the repression the children of Israel asked Moses for help. The prophet prayed God for the punishment to be imposed on the Pharaoh. God responded by sending the flood that sank the houses of the Pharaoh's supporters. ${ }^{31}$ Strangely, that the flood did sink the houses that belonged to children of Israel although it was nearby the people of Pharaoh's houses. Bisri said in al-Ibriz that the people's houses were arranged by Pharaoh in the same row. The house of the children of Israel was side by side with the Coptic's one in the same row. After a few days and flood did not withdraw and was still up to the people's neck, Pharaoh asked Moses to lift the punishment and promised that he would believe in God and release the captives of among the children of Israel. Moses responded and prayed that made the flood suddenly withdraw. ${ }^{32}$

Bisri's interpretation is similar to the interpretation of Tafsir al-

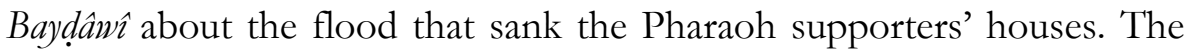
difference is that al-Bayḍâwî did not mention the Coptic houses that was

\footnotetext{
${ }^{29}$ Bisri, Al-Ibrî̌, Vol. 1, 445-447.

${ }^{30}$ Ibid.

31 al-A'râf [7]: 136. So, we exacted retribution from them: we drowned them in the sea, because they rejected Our signs and failed to take warning from them.

32 Ibid.
} 
side by side in the same row with the children of Israel's houses. ${ }^{33}$ About the contest between Moses and Pharaoh magicians, both al-Baydâwî and al-Jalâlayn do not mention the number of the magicians al-Suyûtî in alDurr al-Manthur mentioned that they were seventy people referring to the narration of Ibn 'Abbâs that tells about those who were magician in the morning and martyrs in the afternoon. It means that they were after their defeat and confession to the Moses belief killed by Pharaoh thereof. ${ }^{34}$

The most controversial Bisri's interpretation seems to be on the story of Adam and Eve who allegedly committed shirk in al-A'raf [7]: 189190. The reason is that the story contains details that contradict the doctrine of Islam that all Prophets were credible figures. Although shirk was mainly committed by Eve it is rejected by modernist scholars and taken it out from the tafsir legacy. The concise of the story is that Adam and Eve had baby for twice but each of the baby died. When Eve bore for the third, iblis advised her to give the name for the baby 'Abd al-Hârith. Eve did the advice and the baby survived. According to the rationalist it is impossible that human survival is decided by the name. It is part of shirk in which someone depends on other than God in the life affair. ${ }^{35}$

\section{Hamka's Biography and Isrấîlîyât}

Hamka was born in Sungai Batang, Tanjung Raya, Agam, West Sumatra on February 16, 1908/Muharram 13, 1326 and died in Jakarta, July 24, 1981. His father was Haji Abdul Karim Amrullah (Haji Rasul) b. Shaykh Muhammad Amrullah (title: Tuanku Kisai) b. Tuanku Abdullah Saleh. His mother was Siti Shafiyah Tanjung bt. Haji Zakaria (d. 1934). According to Minangkabau tradition, which is matriarchal, Hamka belonged to his mother tribe, Tanjung. Hamka asserted that his father from the beginning wanted him to be the teacher rather than the author.

\footnotetext{
33 Nâșir al-Dîn al-Bayḍâwî, Tafsîr al-Baydâwî: Anwâr al-Tanzîl wa Asrâr al-Ta'wîl, Vol. 3 (Cairo: Dâr Ihyầ' al-Turâth al-'Arabî, 1997), 31.

${ }^{34}$ Jalâl al-Dîn al-Suyûtî̀, Al-Durr al-Manthûr fì al-Tafsîr bi al-Ma’thûr, Vol. 3 (Beirut: Dâr alFikr, t.th.), 513.

35 Bisri, Al-Ibrí, Vol. 1, 483.
} 
Hamka's carrier however has proven his prominence in both teaching and authorship ${ }^{36}$

Like ordinary teenagers, the little Hamka studied religion and slept in the mosque following Minangkabau tradition that specializes a house for only a female. In the age of six he was brought by his father to Padang Panjang. His contact with a story teller made him knowledgeable about stories, poetries and quatrains (petitah-petitah). ${ }^{37}$ When grown up, Hamka's desire to migrate to Java in finding a new environment was inevitable although his family firmly disagreed. They were afraid of Hamka from being influenced by communism since the ideology rapidly spread in Java. His family finally had no option except to follow and arrange his voyage to Java. Hamka arrived in Yogyakarta in 1924. He found a lot of classical books and learned some disciplines from Ki Bagus Hadikusumo for tafsir, R.M. Soeryopranoto for Sociology; KH. Mas Mansur for philosophy and Islamic History; Haji Fachruddin and H.O.S Tjokroaminoto for Islam and Socialism and to Mirza Wali Ahmad Baig, A. Hasan Bandung and A.R. Sutan Mansur for various disciplines. ${ }^{38}$

Hamka's astonishing presentation in the seminar of "Islam and Minangkabau Tradition" in the $19^{\text {th }}$ Congress of Muhammadiyah in Bukit Tinggi, 1930 was the cause of his rising star in the organization. His standpoint against local tradition was obvious. Hamka exposed some incompatibilities of Adat to Islamic law on which Minang's tradition is matriarchal while Islam is patriarchal. He also criticized the practice of Polygamy that causes to the rise of divorce cases. Hamka's critical view was not surprising since Muhammadiyah divelops the critical paradigm to the existing Islamic paradigm and local tradition that are supported by the traditionalist. $^{39}$

\footnotetext{
36 Wan Sabri Wan Yusof, "Hamka's Tafsir al-Azhar: Quranic Exegesis as a Mirror of Social Change" (ProQuest dissertation and Theses: 1997), 139.

${ }^{37}$ Traditional quatrain of Minangkabau, which each verse consist of two couplets is often delivered in sermons and other traditional occasions in which both host and guest speakers extends welcome and thankfulness using poetry. See Erizal Gani, "Kajian terhadap Landasan Filosofi Pantun Minangkabau," Jurnal Bahasa dan Seni 10, no. 1 (2009): $1-10$.

38 Ibid., 143.

${ }^{39}$ Ibid., 148.
} 
Hamka's life was under logos horizon that drove people criticism and fight for social changing vis a vis Bisri's life under mythos horizon that drove people to submit to the existing paradigm with the Sufis influence of Qadiriyah and Naqsabandiyah Tarekat groups whom were the target of criticism of the reformist Muslims. ${ }^{40}$ Social change aimed by people criticism has eventually impacted to social unrest and conflict like what happened in Hamka's city of birth Minangkabau. The city inherits the history of civil war between the Adat people who represented the status quo against the new comer of orthodox Muslim Paderi group who embraced Wahhabism. ${ }^{41}$

Besides puritanism, Hamka also adopted rationalism as found in his tafsîr work that refers in the big portion to Tafsir al-Manâr of Rashîd Riḍâ. This book becomes the premier reference of Hamka's tafsîr work besides other references like the Reconstruction of Religious Thought in Islam of Iqbal. ${ }^{42}$ Both Ridâ and Iqbal's works show the significance of rationalism being used by the reformist group in building their paradigm. This effort will narrow the gap between religion and science and bring detachment of religion and science to the halt. ${ }^{43}$

Having lived under logos horizon, reformist scholars subdue to the scientific parameter in finding the religious truth. Any given teaching contradicts rationalism will be graded as misconception and needs deconstruction. Hamka deconstructed Islamic teachings in the scope of the country. He paid much attention to the issue of innovation (bid'ab) and superstition (kburafât) that according to Hamka and Muhammadiyah are the most worrying issue in Indonesian Islamic habitus. Hence, he necessarily combated them in any way. ${ }^{44}$

\footnotetext{
40 Yusof, "Hamka's “Tafsir al-Azhar," 150.

${ }^{41}$ Wan Sabri Wan Yusof referring to Schrieke asserted that the war would not take place unless triggered by the interest of the non-religious people, the penghulus and the members of the ruling class by 1818 . Ibid., 92-100.

42 Muhammad Iqbal, The Reconstruction of Religious Thought in Islam (London: Oxford University Press, 1934).

${ }^{43}$ Edward Grant, God and Reason in the Middle Ages (Cambridge: Cambridge University Press, 2004), 152.

44 Adam Schwarz, A Nation in Waiting, Indonesia's Search for Stability (Colorado: Westview Press, 2000), 167.
} 
Hamka's political activity finally brought him to the jail for an accusation on Soekarno assassination conspiracy. Living behind the iron bars was not the cause of Hamka's misery and instead he became a very productive. He took an advantage from the spatial restriction to focus on writing tafsir. The product was extraordinary and considered the masterpiece of more than 100 of Hamka's books. Hamka admitted that living in the jail was a God grace. He might not have accomplished tafsir al-Az̧ar if he was not living behind trellis. ${ }^{45}$

Hamka's paradigm that puts forward the criticism on the existing paradigm particularly on those irrational materials that are abundant in classical tafsîr books led Hamka to express his opposition against isrấallŷât. This clear opposition appears in his interpretation on the story of Eve creation, Hamka mentioned the narration of Ibn Jarîr, Ibn Abî Hâtim, alBayhaqî and Ibn 'Asâkir and many Prophet's companions: "When Adam dwelled in the heaven, he walked lonely with no couple to be the cause of serenity. He slept and when waked up he found beside his head a sitting woman who was made from his rib." Commenting the story, Hamka believed that the narrative is not Prophet's utterance. He belived that it was 'Abd Allâh b. 'Abbâs and 'Abd Allâh b. Mas'ûd's utterance. Since it refers to other than the Prophet, it does not have the same value with the righteous hadith (sahih) and is consequently not taken into consideration in the doctrinal matters. Likely both companions were influenced by the Jewish myth in Madinah and referred to the Genesis chapter 2 verse $21 .^{46}$ In interpreting the story, referring to Muhammad 'Abduh, Muhammad Rashîd Rị̂a in his Tafsîr al-Manâr, Hamka asserted that the hadîth about the woman creation of the rib does not mean physically. It is a metaphoric expression that also there of this kind in al-Anbiyâ [21]: $37 .^{47}$

\footnotetext{
45 Yusof, "Hamka's "Tafsir al-Azhar," 161.

46 Ge: 2:21: And the LORD God caused a deep sleep to fall upon Adam and he slept: and he took one of his ribs, and closed up the flesh instead thereof; Ge:2:22: And the rib, which the LORD God had taken from man, made he a woman, and brought her unto the man.

47 37. Man is a creature of haste: soon (enough) will I Show you My Signs; then ye will not ask me to hasten them! Hamka, Tafsir Al-Azhar, Vol. 15 (Jakarta: PT. Pustaka Panjimas, 1992), 27.
} 
On the story of Hârût and Mârût in al-Baqarah [2]: 102, ${ }^{48}$ Hamka quoted from Tafsîr al-Qur'ân al-'Ażìm of Ibn Kathîr and al-Durr al-Manthûr of al-Suyûtî and said that once upon time angels grumbled and complained that human beings so much transgress God's command. God replied, assumed that you are in their position many of you would do the same. Angels debated it and designated two among them, Hârût and Mârût to descend to the earth. Having arrived at somewhere in earth, they were examined by the very beautiful woman that led them to have sexual intercourse illegally when were drunk. God suddenly angered and offered a punishment of transgression whether to be imposed in the world or hereafter. They preferred in the world so that they are hanged between world and sky. For the beautiful woman, Zuhrah the seducer, she was cursed by God and became Eastern Star that rises in the morning. ${ }^{49}$

Hamka rejected the above story by referring to al-Qurtubî who disbelieve it was narrated by 'Abd Allâh b. 'Umar, the Prophet companion. Instead Hamka said that after scrutinizing story chain of transmission, it is found that it refers to Ka'b al-Ahbâr, the Jewish priest who converted to Islam who was famous with his piety but fond of telling the previous stories (isrấlilyât). Hamka asserted that even though Ibn Kathîr mentioned it in his tafsîr work but he meant to criticize it. Ibn Kathîr strongly rejected the story being transmitted from the children of Israel for two reasons. Because it was not originated from the Prophet (not marfü) and was unqualivied hadîth (not sahîh). To deal with the hadîth, Ibn Kathîr preferred to keep its textual meaning than to use isrấîlìat. . $^{50}$

\footnotetext{
48 102. They followed what the evil ones gave out (falsely) against the power of Solomon: the blasphemers Were, not Solomon, but the evil ones, teaching men Magic, and such things as came down at Babylon to the angels Hârût and Mârût. But neither of these taught anyone (Such things) without saying: "We are only for trial; so do not blaspheme." They learned from them the means to sow discord between man and wife. But they could not thus harm anyone except by Allah's permission. And they learned what harmed them, not what profited them. And they knew that the buyers of (magic) would have no share in the happiness of the Hereafter. And vile was the price for which they did sell their souls, if they but knew!

${ }^{49}$ Hamka, Al-Azhar, Vol. 5, 258-262.

${ }^{50}$ Ibid.; Abû al-Fidâ' Ismâ'îl b. 'Umar Ibn Kathîr. Tafsîr al-Qur'ân al-'Aż\}îm, Vol. 1 (Beirut: Dâr al-Fikr, 1992), 240-242.
} 
Another isrâniliyat circulates on the story of Adam and Eve in alA'râf (7): 189-190. ${ }^{11}$ The story tells that after Adam and Eve descending to earth they both wanted to have baby and God responded it positively. Adam gave the baby's name 'Abd Allâh but then died. Both prayed God for another son and was granted by God another son and he named the baby 'Ubayd Allâh who lived briefly and died like his previous. For the third-time Adam prayed for another son and was fulfilled by God. Following the birth of the third baby, satan whispered Adam to give his baby's name 'Abd al-Hârith that mean the 'Slave of Fertility'. Fortunately, the baby lived long with that name. ${ }^{52}$

According to Hamka, this story whoever its narrator cannot be accepted. Adam after falling to the earth caused by Satan seduction supposedly not to listen from his former seducer. Moreover, it is illogical that Adam's son died because the baby's name 'Abd Allâh and 'Ubayd Allâh? Ibn Kathîr rejected this narration and called it as isrấlilyat that causes transmitter flawed. Hamka reveals the isrâchliy ât impact that is behind the tradition of changing baby's name when he is sick continuously. People assume that the baby is burdened by the heavy name. Unfortunately, the Qur'ânic verse that actually warns Muslim from committing shirk raises an interpretation that inversely causes to someone's shirk by depending on the name changing. ${ }^{53}$

\section{Quraish Shihab's Biography and Isrâ'îlîyât}

Muhammad Quraish Shihab was born in Rappang, Sidenreng Rappang, South Sulawesi on February 16, 1944. He is a prominent scholar in the science of Qur'ân and was the minister of Religious Affair during the last Soeharto era (1998). Quraish was raised in academic family where his father Prof. Abdurrahman Shihab (1905-1986) was a cleric and

\footnotetext{
51 al-A'râf [7]: 199. It is He who created you from a single person, and made His mate of like nature, in order that He might dwell with Her (in love). When They are united, she bears a light burden and carries it about (unnoticed). when she grows heavy, they both pray to Allah their Lord, (Saying): "If Thou givest us a goodly child, we vow we shall (ever) be grateful." al-A'râf [7]: 190. but when He giveth them a goodly child, they ascribe to others a share in the gift They have received: but Allah is Exalted high above the partners They ascribe to Him.

${ }_{52}$ Hamka, Al-Azhar, Vol. 9, 205-210.

${ }^{53}$ Ibid.
} 
professor of tafsir. Quraish's father was important figure in Makassar as a co-founder of Universitas Muslim Indonesia (UMI) and IAIN Alauddin (now State Islamic University/UIN). ${ }^{54}$

Quraish took formal educations for elementary and secondary school in Makassar. In 1956, when he came to the grade 2 of secondary school, Quraish and his younger brother Alwy went to Islamic boarding school Dâr al-Hadîth al-Fiqhîyah, Malang, East Java. They both were excellent students in Arabic and Islamic sciences and won the opportunity to study at al-Azhar High School in Cairo (1958). Quraish continued study under-graduate program at al-Azhar University in the major of TafsîrHadîth and gained the title of Licence (Lc.) In 1967, Quraish took a Master degree at the same campus and finished with his thesis on "Qur'anic Miracle in the Legal Aspect" (al-I'jâz al-Tashrî́n li al-Qur'ân al-Karîm). In 1973, his father recalled him from Cairo to teach in the father's university in Makassar. Being in the country for several years, Quraish decided to continue taking the highest degree of academic. In 1980, he studied a doctorate at the same university of al-Azhar in two years and gained $a$ summa cum laude. He wrote in his dissertation "The Critical Analyzes and

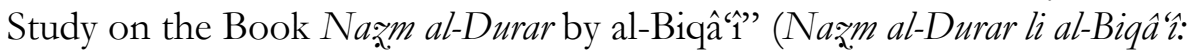
Tahquîq wa Dirâsah). ${ }^{55}$

Quraish admired two figures behind his academic proficiency and owed a lot of gratitude to them. They planted the idealism, value and knowledge that are fundamental to his academic courses in the future. Both figures are Habîb 'Abd al-Qâdir b. al-Faqîh of Malang, Indonesia (d. 1962) and Shaykh 'Abd al-Halîm Mahmûd (1910-1978) of Cairo, Egypt. Habîb 'Abd al-Qâdir taught Quraish for only two years, 1956-1958, nevertheless his influence was deeper than eleven years of study in Egypt. $\mathrm{He}$ was an astonishing figure with a mannerly speaking, eloquent expression, wisdom and sharp mind and always attracted anybody who met him. ${ }^{56}$

54 "Biografi M. Quraish Shihab," www.tafsiralmishbah.wordpress.com (August 30, 2016).

55 The complete name of the book belongs to al-Biqâ̂î̀ is Tafsîr Nażm al-Durar fî Tanâsub al-Ayât wa al-Suwar. See Anshori, "Penafsiran Ayat-ayat Jender dalam Tafsir al-Mishbah" (Disertasi--Universitas Islam Negeri Syarif Hidayatullah Jakarta, 2006), 58.

${ }^{56}$ Mukhlis M. Hanafi, Berguru Kepada Sang Mahaguru (Jakarta: Lentera Hati, 2014), 4-6. 
For many people Quraish is deemed to be the controversial scholar. In his lecture aired live by Metro TV of Indonesia, Quraish answered the question of audience about the legality of hijab and the reason of Quraish's daughters do not wear hijab. Quraish said that hijab has some interpretations. Indonesian women in the era of the beginning of country birth until 1980s did not wear hijab like nowadays' style and were not rigid in dealing with hijab size. They only veiled their hair and let their neck being visible. It was like that for all devout Muslim women including those members of Muhammadiyah and Nahdlatul Ulama organization who wore a simple hijab as also Hamka's wife did. ${ }^{57}$ Another controversy on Quraish's view was about the relationship between Sunni and Shi' in his book Would that be Possible, Sunni and Shiite Go Hand in Hand? (Sunnab-Syiah Bergandengan Tangan, Mungkinkah?). ${ }^{58}$

Quraish began writing Tafsîr al-Misbab on June 18, 1999 in Cairo and launched it on March 29, 2000 when the book has not been accomplished yet until 2004. Hamka and Quraish's work are academically equivalent. It seems that Quraish accomplished Hamka's modern tafsir paradigm. Both employed scientific and historical approaches in contextualizing the text meaning and demythologizing Qur'ânic stories. They produce the same result due to the same references such as Tafsir alManâr of Muhammad Rashîd Rị̂â and Tafsîr fi Zilâl al-Qur'ân of Sayyid Qutb that accentuates the compatibility of the Qur'an to the science. This type of tafsir work was somehow resulted from living under the logos horizon where people principally base their idea on rationalism and empiricism as the truth parameter.

Similar to Hamka, Quraish Shihab pronounces his disagreement to the use of isrâtiliyat. It is apparent at least from his commentaries on the story of Adam allegation to have committed shirk, which is in the same vein with Hamka's one. Quraish said that Adam's obedience to the Satan's whisper to give his son's name 'Abd Allâh al-Hârith, is a kind of shirk. Due to its contradiction with the doctrine of Islam that attribute all God's prophets as the pious figures and did not committed shirk. Nevertheless,

\footnotetext{
${ }^{57}$ https://www.youtube.com/watch?v $=\mathrm{nF} 7 \mathrm{zNPEjJ14/posted} \mathrm{on} \mathrm{July} \mathrm{14,} 2014$ (accessed 22 November 2014.

58 M. Quraish Shihab, Sunnah-Syiah Bergandengan Tangan, Mungkinkah? (Jakarta: Pustaka Lentera, 2007).
} 
Quraish scrutinized the reliability the source that contains the story. AlTirmidhî the author of haditth book has graded it good hadîth (hasan) but strange (gharib) due to the only its single transmitter. Quraish then quoted from Sayyid Qutb calls for not referring to the narration of the Jews and Christians. Similar to Hamka, Quraish prefers to contextualize it to the practice of Makkah disbelievers (mushrik) who used to vow by offering their son for worship. A ritual that associated to shirk due to their dependence to the offering and not directly to God. ${ }^{59}$

On the romance story of King Solomon and Queen Sheba (Bilqis) that was narrated to end to marriage (QS. al-Naml [27]: 44), Quraish suggested to remove it from the Islamic legacy. Muslims is instead suggested to take the lesson from the positive story such as Solomon's humble to God although he was tremendous king. ${ }^{60}$ Romance story is unappropriated material to be included in the religious discourse. Quraish also reject an isrấlikyat that exposes too awful detail of the story. Such as the story of Job's in Ṣ̂d [38]: 41 that exposes the physical repugnance during Job's suffering of the disgusting skin sickness is indecent material to be known by many people. Quraish said that the narration of the story may refer to the Jewish sources. ${ }^{61}$

\section{Bisri's Tolerance towards Isrấîlîyât and Hamka and Quraish's Rejection against it}

The above explanation exposes of Bisri, Hamka and Quraish's interpretations on some stories, indicate their inclination toward the use of tradition and rationalism in the same time or to use both tradition and reason-based Interpretation. They do not leave the interpretation of the early generation such as Ibn 'Abbâs and Ibn Mas'ûd and 'Ikrimah as long as the narration is plausible. Otherwise they will condemn it as fake or weak or judge it to be originated from Jewish or Christian sources or other nation's culture. It seems to say that the righteous narrative must be in accordance with the reason. Such as the story of Eve creation from Adam's rib, despite its narrators were among trustworthy Prophet's

\footnotetext{
59 M. Quraish Shihab, Tafsir al-Mishbah: Pesan, Kesan, dan Keserasian al-Qur'an, Vol. 5 (Jakarta: Lentera Hati, 2002), 415.

${ }^{60}$ Ibid., Vol. 9, 453.

${ }^{61}$ Ibid., Vol. 11, 392.
} 
companions, Hamka preferred not to take it. Assumed that he takes it, he will understand it allegorically by referring to Rashîd Riḍ̂ who said that a woman is like human's rib, which is not straight, easily broken and labile. This kind of interpretation is actually not recommended by Ibn Taymiyah, the leader of puritanism whose paradigm inspires many reformist and modernist group. Ibn Taymiyah taught that when the text has obvious meaning it is forbidden to interpret it beyond textual meaning. ${ }^{62}$ It indicates that Hamka's paradigm is closer to Rashîd Rị̂a than to Ibn Taymiyah.

The degree of rejection on isrâtiliyat is determined by the degree of its irrationality. When the story is ridiculous, both Hamka and Quraish will suddenly reject it. Such as on the story of the desertion of a group of children of Israel from the defected majority in which they went through underground tunnel until arrived at China. Besides, the story of Adam obedience to the Satan whisper, these two stories are totally rejected by both prominent Indonesian mufassir.

When the story is not ridiculous but not important to be included in an interpretation, they will reject it as well. Such as about the name of the people of the cave and the name of the man whose science of the book was able to remove Bilqis' throne to Solomon palace in only a blink. Hamka commented that the name is unnecessary to be detailed and not supposedly made Muslim to curious about. Nonetheless, Hamka did not reject whatever isrấlilyat. He took into his consideration the rational isrấlilyat like the story of the crow and the dove with the olive that were commanded by Jonah to find the dry land for the ship anchorage. The story is responded positively by Hamka for its accordance with the Qur'ânic perspective.

The development of reason causes to the rise of mufassir criticism. Mufassir's total submission to the authoritative book has changed to the partial submission based on rationality. What appear in the Hamka and Quraish's still accommodate both tradition and reason exercise or mythos and logos. ${ }^{63}$ Nevertheless, when the tradition contains irrational explanation

\footnotetext{
62 Abdullah Saeed mentioned the other term similar to tradition-based tafsîr: riwâyah and for reason-based tafsîr, dirâyah, and ta'wîl. See Abdullah Saeed, Interpreting the Qur'ân: Towards a Contemporary Approach (USA and Canada: Routledge, 2006), 62.

${ }^{63}$ Ibid., 59.
} 
of the Qur'ânic story, Hamka will leave the tradition and prefer to keep the textual meaning and contextualize it with the contemporary circumstances.

The figure of Ka'b al-Aḥbâr becomes the target of Hamka's attack in at least three stories: Hârût and Mârût, Gog and Magog and Dhû alQarnayn. Hamka said that many irrational stories being transmitted by companion when traced back would potentially end to Ka'b al-Aḥbâr as the first informant. Nevertheless, Hamka acknowledged that he was a pious man despite of his hobby to spread weird stories. It indicates Hamka embraced an ethical consideration not to insult Ka'ab seriously despite his obvious position against isrấrlîyât.

Beside Ka'b, the Bible and the unidentified Jewish and Christian sources are also accused to be the introducer of ridiculous stories to the book of tafsir. Hamka's accusation and attack to both sources indicate his level of intellectuality that have elevated from the level paradigm to the level of 'perfect ideology' (borrowing the term of Panikkar). Someone's eagerness to attack will not happen unless he was convinced with the truth of his ideology. He assumed that his ideology was the perfect one and it is his duty to disseminate it to anybody using any methods including the offensive one. However, it also tells an anomaly when found Hamka and Quraish on the other cases use Bible to support his idea.

\section{Conclusion}

Bisri used isrấlilyât for Qur'anic stories commentary. He did not mind with the irrational content of isrấlilyat. What mattered to him seems to be on the reference of the stories whether they stem from the authoritative books or not. Nevertheless, Bisri selected the most rational one among those isrấilyyat. Instead of coming with the new interpretation that is in line with the people rationalism, Bisri preferred to develop cultural approach as an effective media to disseminate his tafsîr by using Javanese and Arabic letters. Bisri's tolerance to the use of irrational was supported by his background of traditionalism whose idea to preserve the existing paradigm rather than to change and renew it with the ideas of rationalities.

Hamka and Quraish have the same negative viewpoint on isrấlilyat. They both rejected isrấlîyat for its incompatibility with the 
reason. Many isrâchlîyat appear in the tafsir book and seemingly to tell nothing but irrational stories. Instead of employing isrấlilyat abundant in the classical tafsir books he both preferred to refer to the contemporary tafsir works written by the revivalist scholars of the Egypt. Besides they both employed science and philosophy that contributed significantly to the bringing tafsir to the more rational thoughts. Hamka has reached this paradigm was because of his background of among reformist family. Quraish has likewise reached this stage of rejection on isrấalityat because of his academic family that invested rationalism to Hamka's paradigm. Nevertheless, comparing to Hamka, Quraish rejection on isrâtillŷat is less harsh than Hamka. It is because Quraish besides his rationalism was also influenced by the figures that practiced sufism and performed the Islamic tradition like tablilan that is the object of criticism of reformist Muslim fellow.

\section{Bibliography}

Amin, Samsul Munir. Karomah Para Kiai. Yogyakarta: Pustaka Pesantren, 2009.

Anshori. "Penafsiran Ayat-ayat Jender dalam Tafsir al-Mishbah." Dissertation-Universitas Islam Negeri Syarif Hidayatullah Jakarta, 2006.

Anshoriy, Nasruddin and Pembayun. Pendidikan Berwawasan Kebangsaan: Kesadaran Ilmiah Berbasis Multikuluralisme. Yogyakarta: LKIS, 2008. Barnavi, Eli. A Historical Atlas of the Jewish People, from the Time of Patriarch to the Present. New York: Alfred A. Knop, 1992.

Bayḍâwî (al), Nâșir al-Dîn. Tafsîr al-Baydâmû́: Anwâr al-Tañîl wa Asrâr alTa'mûl, Vol. 3. Cairo: Dâr Ihyâ'’ al-Turâth al-'Arabî, 1997.

Fadeli, Soeleiman. Antologi NU: Sejarah, Istilah, Amaliah Uswah. Surabaya: Khalista, 2007.

Federspiel, Howard M. Persatuan Islam Islamic Reform in Twentieth Century Indonesia. New York, NY: Monograph Series Cornell University, 1970.

Federspiel, Howard M. Popular Indonesian Literature of the Qur'an. New York: Cornell Modern Indonesian Project, 1994. 
Firestone, Reuven. "Abraham's Journey to Mecca in Islamic Exegesis: A Form-Critical Study of a Tradition." Studia Islamica, no. 76 (1992): 5-24.

Gani, Erizal. "Kajian terhadap Landasan Filosofi Pantun Minangkabau." Jurnal Bahasa dan Seni 10, no. 1 (2009): 1-10.

Grant, Edward God and Reason in the Middle Ages. Cambridge: Cambridge University Press, 2004.

Hamka. Tafsir Al-Az̧ar, Vol. 5, 9, dan 15. Jakarta: PT. Pustaka Panjimas, 1992.

Hanafi, Mukhlis M. Berguru Kepada Sang Mahaguru. Jakarta: Lentera Hati, 2014.

Ibn Kathîr, Abû al-Fidâ' Ismâîil b. 'Umar. Tafsîr al-Qur'ân al-'Ażîm, Vol. 1. Beirut: Dâr al-Fikr, 1992.

Iqbal, Muhammad. The Reconstruction of Religious Thought in Islam. London: Oxford University Press, 1934.

Jindrich, Harry. "Indonesia Islam Under the Japanese Occupation, 194245," paper at the Annual Conference of the Far Eastern Association, Washington D.C. (March 1955).

Lubis, Mochtar. Indonesia, Land under the Rainbow. Singapore: Oxford University Press, 1987.

Maḥallî (al), Jalâl al-Dîn Aḥmad and Jalâl al-Dîn al-Suyûṭ̂, Tafsîr al-Jalâlayn. Cairo: Dâr al-Hadìith, 1980.

Margoliouth, D.S. The Relation between Arabs and Israelites Prior to the Rise of Islam. London: The British Academy, 1924.

Musîrî (al), Abd al-Wahhâb Muhammad. Mawsû́ ât al-Yahûd wa al-Yahûdîyah wa al-Șabyunîyah. Cairo: Dâr al-Shurûq, 2015.

Mustofa, Bisri. Al-Ibrìz li Ma'rifat Tafsîr al-Qur'ân al-A₹̨̣̌, Vol. 1. Kudus: Maktabah Menara Kudus, t.th.

Muzadi, Abdul Muchith. Mengenal Nabdlatul Ulama. Jember: Masjid Sunan Kalijaga, 2006.

Panikkar, R. Myth, Faith, and Hermeneutics. Bangalore: Asian Trading Corporation, 1983.

Ricklefs, M. C. A History of Modern Indonesia since c. 1300. Hampshire: Palgrave MacMillan, 2001.

Saeed, Abdullah. Interpreting the Qur'ân: Towards a Contemporary Approach. USA and Canada: Routledge, 2006. 
Schwarz, Adam. A Nation in Waiting, Indonesia's Search for Stability. Colorado: Westview Press, 2000.

Shalabî, Ahmad. Al-Yabûdîyah. Cairo: Maktabah al-Nahḍah al-Mișrîyah, 1996.

Shihab, M. Quraish. Tafsir al-Mishbab: Pesan, Kesan, dan Keserasian al-Qur'an, Vol. 5, 9, dan 11. Jakarta: Lentera Hati, 2002.

Shihab, Quraish. Sunnah-Syiah Bergandengan Tangan, Mungkinkah?. Jakarta: Pustaka Lentera, 2007.

Suyûtịi (al), Jalâl al-Dîn Al-Durr al-Mantbûr fî̀ al-Tafsîr bi al-Ma'thûr, Vol. 3. Beirut: Dâr al-Fikr, t.th.

Tymieniecka, Anna-Teresa, ed. Reason, Spirit, and the Sacral in the New Enlightenment: Islamic Metaphysics Revived and Recent Phenomenology of Life. New York: Springer, 2011.

Yusof, Wan Sabri Wan. "Hamka's Tafsir al-Azhar: Quranic Exegesis as a Mirror of Social Change." ProQuest dissertation and Theses: 1997.

Zamakhasharî (al), Abû al-Qâsim Maḥmûd b. 'Amr. Tafsîr al-Kashshâf, Vol. 4. Beirut: Dâr al-Kutub, 1407.

https://www.tafsiralmishbah.wordpress.com (accessed 30 August 2016).

https://www.youtube.com/watch?v $=\mathrm{nF} 7 \mathrm{zNPEjJ14/posted} \mathrm{on} \mathrm{July} 14$, 2014 ( 22 November 2014). 